\title{
Finding a Place for Critical Thinking and Self-voice in College English as a Foreign Language Writing Classrooms
}

\author{
Dr. Osman Z. Barnawi \\ English Language Center, Yanbu Industrial College, Saudi Arabia \\ P.O. Box 8733, Makkah, Saudi Arabia, Zip code: 21955 \\ Tel: 966-555-99-7817_E-mail: albarnawim@hotmail.com
}

Received: August 3, 2010 Accepted: November 18, 2010 doi:10.5539/elt.v4n2p190

\begin{abstract}
Although the concepts of critical thinking and self-voice have been extensively discussed in a second language writing, little attention has been given, on the pedagogical level, to critical thinking and self-voice in college EFL writing instruction. To fill such a void, this paper attempts to propose some pedagogical tasks namely: persuasive writing tasks, draft workshops one-on-one mentoring approaches for finding a place for critical thinking and self-voice in EFL classrooms. In doing so, this paper provides the operational definitions of critical thinking and self-voice concepts. It then discusses how these two concepts are closely related to complement EFL writing learning. In what follows, it presents the rationale for finding a place for critical thinking and self-voice in EFL writing. It then touches on some pedagogical practices for developing critical thinking and self-voice in classrooms. Lastly, it addresses some challenges related to implementing critical thinking and self-voice tasks in EFL classrooms.
\end{abstract}

Keywords: EFL writing instruction, Critical thinking, Self-voice, Pedagogical tasks.

\section{Introduction}

Writing, by and large, occupies a vital role in our personal and professional lives. Therefore, it is not surprising that writing/composition courses have been perceived as one of the indispensable components in both university and college English curricula. Today most college writing programs call attention to the importance of critical thinking and self-voice skills necessary for academic success and for lifelong learning endeavors (Alagozlu, 2007; Massi, 2001). Rather than blindly accepting the ideas of others, college student writers are expected to critically question the validity of ideas in written texts, and they are encouraged to judge the ideas of other people to show authorial presence, which shows autonomy of their thoughts.

This notion of critical thinking and self-voice in writing, however, is neglected in many English as a foreign language (EFL) college writing classrooms. More specifically, little attention has been given, on the pedagogical level, to critical thinking and self-voice in college EFL writing instruction. One possible reason might be that critical thinking and self-voice are not acceptable in the traditional educational system. Therefore, EFL teachers often believe that because their students have not been taught to think critically and independently in their first language (L1) writing, they may lack critical thinking and individualized voice in their second language (L2) writing (Ramanathan \& Atkinson, 1999). Another reason may be that college EFL teachers have not paid much attention to the notion of critical thinking and self-voice in their writing instructions as they often assume that their students are incapable of critically positing their voices, judgment and beliefs into written texts. However, these assumptions are questionable and worthy of further investigation.

Further reason might be that "[EFL] students are deficient in critical thinking abilities because they have been raised under social practices where group harmony and conformity are stressed" (Stapleton, 2001, p. 509). Thus, it is mostly assumed that in EFL writing instruction, for example, college students provide mere loyalty to texts given as course materials (e.g., course-books and hand-outs). As a result, they have great difficulties when composing essays in English as they cannot easily incorporate their own voice or ideas into the essays.

Informed by post-process theories of composition, this paper attempts to propose some pedagogical tasks for finding a place for critical thinking and self-voice in EFL college composition classrooms. This is because post-process theories of compositions suggests that writing "is always social: subjectivity is multi-valenced and multi-voiced; writers and readers are always conditioned and interpolated by networks of social relations; and the goal of composition is in part about raising students' awareness of their own discursive formations" (Allison, 2002, p. 1). It 
is worth noting here that the assumption behind building on post-process theories of composition rather than critical pedagogies is that the latter primarily focuses on political aspects of the classroom such as structural, bureaucratic, and policy constraints, whereas the former views composition from a social perspective. Moreover, it is believed that, in reality, theories of critical pedagogies are imbedded within post-process theories of composition - these two theories are not mutually exclusive, instead, post-process theories of composition offer an opening space for critical pedagogies in combining them with other theories (e.g. social theories).

Before discussing how to find a place for a critical thinking and self-voice in college EFL writing classrooms, this paper will address theoretical and empirical accounts of critical thinking and self-voice from the perspective of post-process theories of composition and the benefits that students will gain from such notions in writing. First, the paper provides the operational definitions of both critical thinking and self-voice to give the audience a clear understanding of these concepts. It then discusses how critical thinking and self-voice are closely related to complement foreign or second language writing and learning. In what follows, the paper presents the rationale for finding a place for critical thinking and self-voice in EFL writing. It then touches on some pedagogical practices for developing critical thinking and self-voice in EFL college writing/composition classrooms. Lastly, the paper addresses some challenges related to implementing critical thinking and self-voice tasks in EFL writing classrooms.

\section{Critical thinking in L2 composition classrooms}

Today many EFL educators stress the needs for teaching critical thinking in EFL college writing/composition classrooms; however, this concept has been defined differently by different researchers and educators. The emergence of these different definitions is due to its cognitive nature in which critical thinking is seen as an "ongoing activity" (Canagarajah, 2002, p. 101) and student writers are expected to attain the ability to think critically as they go through process-oriented activity. Beyer (1995, p. 8), for example, defines critical thinking as "...making reasoned judgments," which may connote using critical thinking to judge the quality of something, from "cooking to a conclusion of a research paper" (Alagozlu, 2007, p 119). In the same vein, Liaw (2007) defines critical thinking as something which "involves the use of information, experience, and world knowledge in ways which allow [EFL students] to seek alternatives, make inferences, pose questions, and solve problems, thereby signaling understanding in a variety of complex ways" (p.51). Critical thinking is also defined as a cognitive ability compounded with multiple skills such as identifying, understanding, and analyzing an issue by deploying inferences using top-down and bottom-up strategies to validate the reliability of claims and arguments (Pithers and Soden 2000). This view suggests that critical thinking is a complex concept that can be used to support assumptions, information, and claims in EFL writing.

In this paper, the concept of critical thinking in L2 writing is defined as an ability to analyze facts, produce and organize ideas, maintain opinions, make comparisons, judge arguments, and solve problems by the use of existing information, previous knowledge, experience, and world knowledge when writing. In this regard, if ideas or arguments are operated from the existing information, students are able to transform their ideas or arguments into their own words. If ideas or arguments come from students' previous knowledge or experience, students are able to articulate such ideas into their written work. The use of previous knowledge or experience is perceived as a facilitating tool for generating ideas or arguments when writing. This is because such previous knowledge or experience can be captured by social mediation between teachers and students or peers. Social mediation can serve as a tool of negotiating students' arguments, which may lead to students' critical thinking development.

In a practical sense, researchers such as Knott (2005) point out that in a written text, students are to be aware of following issues: (i) the main claims or purpose of the text —an attempt to judge how these claims are built up or argued, (ii) judgment of context - understanding the nature of the context, (iii) justifications provided in the written text, (iv) evidence provided in the written text (e.g., facts or figure), and (v) the strengths and weaknesses of claims. This notion suggests that student writers need to initiate some content (e.g., organization community as will be explained later in the pedagogical section) in order to make assumptions and/or arguments that they can then analyze, defend, judge and from which they can draw conclusions.

In order for EFL teachers to assess a written text provided by their students in terms of critical thinking, Stapleton (2001) proposes six main criteria which are as follows: (a) arguments - claims supported by a reason such as facts and figures. It is worth noting, however, that unsupported claims are opinions and cannot be classified as an argument. (b) reasons - statements which are used to support claims, (c) evidence-statements which are used to support arguments, (d) recognition of opposition and refutation - counteracting opinions which offer alternative explanations to those expressed in the claim, (e) conclusion - a statement/s in which the writer tries to persuade the readers to trust in his or her beliefs, and (f) fallacies - pitfalls in reasoning which imply inadequate support for the writer's claims. 
In essence, it could be argued that critical thinking is a socio-cognitive process in which interpersonal and intrapersonal interactions are vital when composing or writing. In other words, during the writing process, the student writer interacts with audiences in a specific context, and then at an intrapersonal level, the student-writer filters the interaction through his or her experiences, observations and prior knowledge. As Ramanathan and Atkinson (1999) convincingly argue, in order for a student writer to think critically, he or she must have an individual voice that is not affected by the concepts of 'collectivism' or any other foreign agent such as alternative claims or arguments. Such an assertion implies that in order to possess the ability of critical thinking skills in writing, a student writer must have the freedom to voice his or her ideas comfortably. In other words, critical thinking and self-voice seem to be inextricable in foreign or second language writing and learning.

\section{Self-voice in $\mathbf{L} 2$ composition classrooms}

The term "voice", by and large, is a metaphorical concept that stemmed from Bakhtin's work and, "it is used in such a loose and celebratory way as to mean almost anything" (Elbow, 1994, p 2). Therefore, in L2 writing/composition the concept of self-voice has been defined differently by different researchers and educators. Researchers such as Matsuda, (2001), for example define self-voice in writing as an individual's authorial identity or authorial presence which reflects his or her autonomy of thoughts from other writers. Similarly, Ivanic and Camps, (2001, p.7) define self-voice in writing as "expressions of the writer's own views, authoritativeness, and authorial presence." In this regard, they see factors such as writer's beliefs and values, the way the writer views his or her relationship with audiences, and the way the writer posits meaning into a written text as contributing factors to how language shapes, constructs and deconstructs the writer's self-voice. The concept of self-voice is also defined as writing that "captures the sounds of the individual on the page" (Elbow 1981, p. 287).

From the above definitions of self-voice, it could be argued that in L2 writing also "the voice of the individual is a reflection of multiple voices" (Stapleton, 2002, p. 178). These multiple voices are socially constructed in which individuals' voices are "socially available yet ever-changing repertoires" (Matsuda, 2001, p. 40). To put it simply, an individual voice is seen "as a process of continually creating, changing, and understanding the internal and external identities that cast us as writers, within the confine of language, discourse, and culture" (Hirvela \& Belcher, 2001, pp. 90-91)

Accordingly, in this paper the concept of self-voice is defined as a characteristic of writing that "individuates a writer from other writers as evidenced in that writer's texts" (Ramanathan and Atkinson 1999, p. 49). Self-voice in writing is seen as "(1) audible voice or intonation (the sounds in a text), (2) dramatic voice (the character or implied author in a text), (3) recognizable or distinctive voice, (4) voice with authority, and (5) resonant voice or presence (Elbow, 1994, p. xx). This view suggests that the attainment of self-voice in writing takes place via a range of "rhetorical and linguistic resources" (Hyland, 2002, p.1093).

In a practical sense, as Alagozlu (2007) convincingly argues, "the identification of authorial voice in written discourse proves quite difficult as it involves voice appropriation which is not a straightforward citation of other people's ideas, but rather a complex set of linguistic strategies" (p.121) such as the use of first person and second person pronouns 'I' and 'you', vocative 'hey guy' and explicit voice marker 'in my opinion' (Scollon et al., 1998 p.232).

Overall, based on the above discussion it could be argued that self-voice in L2 writing is a crucial skill that EFL college teachers should teach in writing/composition classrooms. The argument is that the attainment of self-voice in writing seems to help the student writer to posit his or her ideas, experiences and pervious knowledge into written texts. Additionally, it may allow the student writer to construct and de-construct his or her own voice as these voices are historically, culturally, socially and linguistically situated. To achieve this end, the student writer should gain critical thinking competence, which leads students to voice their own ideas or arguments based on a specific academic discourse (Alagozlu, 2007; Hyland, 2002). This view suggests that critical thinking and self-voice in writing/composition are not mutually exclusive. Instead, they should be seen as dual competencies in college EFL writing/composition instruction. Figure one below depicts the correlation between critical thinking and self-voice in college EFL writing instruction.

Insert Figure 1. Here

Having discussed the concepts of critical thinking and self-voice in writing/composition, the question of why college EFL writing/composition teachers need to teach these skills logically arises.

\section{The needs for critical thinking and self-voice in EFL college writing classrooms}

Undoubtedly, in many Asian cultures like Saudi Arabia (Barnawi, 2009), Turkey (Sert, 2006), China (Liu, 2005) and Japan (Stapleton, 2001) social values such as authority, social harmony and deference to elders and teachers are highly appreciated. In the Saudi context, for example, EFL students used to perceive the teacher as a figure of authority and 
the only source of knowledge who should not be questioned. Likewise, Sert (2006) argues that due to the current teacher-dominant classrooms that do not encourage questioning and showing disagreement in academic discourse, most Turkish college EFL students lack skills such as self-assessment and monitoring their own process of language learning. These traditional teaching situations in Saudi Arabia and Turkey, for example, seem to indicate that elements such as critical thinking and self-voice are not emphasized explicitly within the educational system. However, the fact cannot be denied that the L2 students do possess critical thinking skills and self-voice in writing. In other words, these traditional teaching situations seem "to fit into the didactic approach or concept-based instruction in the classic educational system where learning is centered on the retention of previously learned information and where no thinking is required" (Alagozlu, 2007, p.131). Consequently, most college EFL students still suffer from weakness in expressing their original ideas or thoughts in writing - constructing arguments, making claims supported with reasons and evidence from the texts they read. They tend to write or copy what they have read instead of filtering it through their own judgment and reasoning.

Critical thinking and self-voice are indispensible ingredients in EFL college writing/composition instruction, which will allow students to express themselves clearly, and put their own viewpoints into their writing. Moreover, teaching critical thinking and self-voice in writing will not only help students to identify, evaluate, construct and support arguments by using their prior knowledge, experience and other sources of information, but it will also help them monitor and assess their own learning processes.

Additionally, critical thinking and self-voice in writing help students to examine and question logical relationships among statements or data and to infer a conclusion from one or multiple premises. In this regard, elements such as ambiguity and doubt facilitate a critical-thinking function and are an essential ingredient of the critical thinking process, provoking the student writer to pursue the issue until he or she reaches a reasonable conclusion (Beyer, 1995). To put it simply, critical thinking and self-voice in writing help students to question every claim or argument that may be weak in reasons and logic.

Although some researchers oppose the idea of teaching critical thinking and self-voice in EFL college writing and argue that it is not necessary to conform to Western teaching standards, a combination of Western and Eastern teaching standards will deepen students' language competence in writing. In other words, equipping student writers with both Eastern and Western versions of critical thinking and self voice will empower their knowledge construction process, prompting student writers to think locally and act globally. In this regard, it is important to mention some differences between the Eastern and Western versions of critical thinking and self voice in writing. In the Eastern standard of critical thinking and self-voice in writing, the student writers usually shy away from stating their opinions, beliefs and/or conclusions clearly, leaving the readers to draw their own, whereas in the Western standards the student writers believe that when they write (e.g., an essay) it is important to state their opinions and/or conclusions clearly, even if the topic is controversial. This notion suggests that Eastern student writers seem to have a desire to maintain harmony, to not rock the boat, whereas the Western student writers seem to judge the ideas of other people to show authorial presence, which shows autonomy of their thoughts.

In short, the above outcomes of critical thinking and self-voice in writing suggest that EFL students need to be supported in terms of developing their critical thinking and self-voice skills to overcome the difficulties in EFL writing/composition and to cope with the requirements of the multicultural world. However, this raises the question of what possible pedagogical practices college EFL writing/composition teachers might implement in order to help their students gain critical thinking and self-voice skills in their writing, which will further situate their own writing into multiple contexts through rhetorical and linguistic exploitation, and play roles as text transformers, not text transmitters or consumers.

\section{Pedagogical tasks for finding a place for critical thinking and self-voice in EFL writing classrooms}

Since there are many ways to pull the theories of critical thinking and self-voice into writing/composition instruction, this paper will propose pedagogical tasks that are derived from Kent's (1993, p.165) work which sees writing as a 'hermeneutic guessing game'-in which one engages in order to communicate with others. In such guessing games, any language user cannot ever really know or predict what will happen as a result of such engagement. Though it is beyond the scope of this paper to elaborate on Kent's notion of 'hermeneutic guessing game', in adapting some of his notions, the student writers are always eager for instruction that is adapted to their own judgments, values, beliefs, and experiences. Such an instruction offers cognitive-humanistic interactivity in which student writers turn their ideas, beliefs and experiences into written texts in order to meet ideational and textual functioning. This instruction will also help student writers articulate their ideas into readable written work to meet interpersonal functioning. Therefore, possible pedagogical tasks that EFL composition teachers may employ to accommodate student writers' eagerness can be implemented through persuasive writing tasks, draft workshops, and through the one-on-one "mentoring" approach 
that Kent (1993 p.165) envisioned. This is because critical thinking and self-voice in writing are both situated practices - students produce texts so as to achieve particular interests and purposes and social practice. There is a dialogic interaction between a writer and audience(s).

\subsection{Persuasive writing}

Sample One

Instructions:

$>$ Choose community organizations that are physically close to you.

$>$ Try to identify a specific problem that you want to solve.

$>$ Try to persuade the readers why you think it is a problem that needs to be solved.

$>$ Use your own observation, experience, prior knowledge and other informational sources to support your claims/arguments.

Sample Two

Instructions:

$>$ Consider an argument that you might have had with friends or family.

$>$ Try to develop from these experiences what they considered to be the elements of successful persuasion.

The above writing tasks are designed to help a student writer gain critical thinking and self-voice skills in the writing/composition classroom. First, such tasks not only help the student writer to brainstorm, identify, analyze, evaluate, construct and support arguments by using his or her prior knowledge, experience and other sources of information, but they will also help him or her monitor and assess his or her own learning process. Second, these tasks engage the student writer with discourses that are both real and significant in his or her daily life. Third, such tasks urge the student writer to work enthusiastically in order to meet the real needs and expectations of a community audience by taking his or her writing beyond the classrooms.

It should be mentioned, however, that the student-writer may experience difficulties in terms of identifying or choosing a specific organization or problem to write about. In this regard, as Yarbrough's (1999, p. 240) clearly asserts, "in most cases students already perceive problems they want to be able to solve and have questions they want to be able to answer". If it appears that a student writer could not recognize a specific organization or problem, peers and teacher's scaffolding is necessary.

\subsection{Draft workshops}

\subsubsection{Lecturing}

In the draft workshop, the teacher should employ two tasks: lecturing, and contrastive-critical framing and transformed practice. The teacher should take a moment in the classroom to spell out the goals of a writing task (i.e., to enhance critical thinking and self-voice skills). In other words, the teacher should discuss with the students the implications of what it means to consider the beliefs of others in persuasive writing, to make claims and to support your arguments. This will help students "think through the implications of writing for an audience with which they might not share common ground” (Heard, 2007, p. 295). The teacher may employ Yarbrough's notion (1999, p.177), which states that "if I say the room is cold and you say it is hot, and we each believe that what we say is true, then the causes of our meanings are obviously different. The aim of communication is to locate those causes".

\subsubsection{Feedback: Contrastive-critical framing and transformed practice}

The teacher can help students refine their writing through the use of "contrastive-critical framing" and "transformed practice" tasks adapted from The New London Group's terms (1996). The former refers to a task that encourages students to collaboratively compare and contrast the original and revised versions of their writing critically. The latter is perceived as a task that urges students to collaboratively transform what they have negotiated or discussed, which contributes to possible solutions to the problems noticed during the feedback process. The reason for using those two pedagogical tasks is to achieve the goals of negotiated and process-oriented feedback.

In contrastive-critical framing tasks, groups/pairs of students are asked to collaboratively respond to each others' drafts, and teachers may act as readers as well. Afterwards, students and teachers notice or identify gaps or problems; the foci of gaps or problems include form, content, organization, ideas and beliefs. Then, groups/pairs of students are asked to recognize sources of gaps or problems. These sources can be derived from differences between their mother tongue and a target language and social as well as cultural differences. Based on the contrastive-critical framing, students work on a transformed practice task. This task urges students to transform the negotiated solutions 
for the gaps identified. Figure two below provides a global picture to the process of contrastive-critical framing" and "transformed practice".

Insert Figure 2. here

These tasks have enormous benefits with regard to critical thinking and self-voice skills in writing/composition classrooms. The negotiation between peers and teachers encourages students to have critical discussions for finding solutions to the gaps noticed or identified. Moreover, conflict or disagreement in that negotiation provides an impetus for students to re-examine their language use, arguments, and organization clarity in their writing, as Swain and Lapkin (2002) pinpoint.

\subsection{Individual conferencing}

Individual conferencing is crucial to help a student-writer gain critical thinking and self-voice skills. This is because, for example, in a workshop when responding to each other's drafts, students may be reluctant to spot some gaps or problems because they (1) would like to provide positive comments to maintain harmony in groups, (2) do not like to hurt others' feelings, and (3) think that those who should provide negative feedback are teachers because they have the sole authority to assess students' pieces of writing (Nelson \& Carson, 2006). Spotting others' mistakes or problems in others' writing causes embarrassment. This face-threatening issue hinders students from being critical in commenting on others' drafts. So during an individual conferencing, the teacher may help students to overcome such cultural problems.

\section{Challenges for implementing critical thinking and self-voice in writing/composition classrooms}

Although the above three tasks: persuasive writing, draft workshop and individual conferencing seem to balance post-process theory with the traditional instruction of EFL college writing/composition, there are some challenges that both the teacher and the students may encounter when implementing the notion of critical thinking and self-voice in their writing classrooms.

College EFL writing/composition teachers may argue that it is hard to begin to teach critical thinking and self-voice skills in traditional classrooms where the teacher dominates the students' thinking processes by imposing his or her own opinions and ideas. Student writers may also reject the notion of critical thinking and self-voice because they always believe and trust that knowledge is transmitted by their teachers. In this regard, writing teachers need to make a commitment to work with the theory of critical thinking and self-voice and implement it in their classrooms so that student-writers take the risk of expressing their individual voice, ideas, thoughts in writing and gain confidence to oppose others' ideas based on their own reasons and logic. This is because such notions will remain unused if writing teachers do not begin to experiment with their current given space or context.

With regard to students' readiness to accept such a teaching philosophy in their college writing classrooms, as mentioned earlier, students are always eager for a teaching style that is adopted to their own values, beliefs, experience and prior knowledge, and a teaching style that shapes their analytical, critical and expressive faculties both in writing and in attaining successful communication. Moreover, teaching critical thinking and self-voice in writing often requires a moment-by-moment, class-by-class commitment to help students possess such skills through engagement and interaction. Therefore, college EFL teachers have to make a commitment to work with the theory of critical thinking and self-voice and to implement it in their classrooms in order to ensure the success of such a notion.

In conclusion, this paper attempts to re-envision some pedagogical tasks for incorporating critical thinking and self-voice into college EFL writing/composition classrooms. These pedagogical tasks attempt to offer possibilities rather than certainties aimed at urging EFL teachers in different contexts to redesign other possible pedagogical tasks, which suit their particular foreign or second language learning and teaching context, goals, and expectations. More importantly, conducting an empirical study might help us gain more understanding about the feasibility of such proposed tasks and contribute to the continuing discussion regarding critical thinking in self-voice in EFL writing classrooms.

\section{References}

Alagozlu, N. (2007). Critical thinking and voice in EFL writing. Asian EFL Journal, 9, 118-136.

Allison, F. (2002). Houses divided: Processing composition in a post-process time. CollegeLiterature. [Online] Available:http://findarticles.com/p/articles/mi_qa3709/is_200201/ai_n9067589/?tag=content;col1 (July, 20, 2009)

Beyer, B. K. (1995). Critical thinking. Bloomington, IN: Phi Delta Kappa Educational Foundation.

Canagarajah, A. S. (2002). Critical academic writing and multilingual students. Ann Arbor, MI: The University of Michigan Press. 
Elbow, P. (1981). Writing with power. Oxford University Press. New York.

Elbow, P. (1994). Introduction. In P. Elbow (Ed.) Landmark essay on voice and writing (pp.xi-xvii). Davis, CA: Hermagoras Press.

Heard, M. (2007). What should we do with postprocess theory? Pedagogy: Critical approach to teaching literature composition, and culture, 8, 283-304.

Helms-Park, R., \& Stapleton, P. (2003). Questioning the importance of individualized voice in undergraduate L2 argumentative essay: An empirical study with pedagogical implications. Journal of Second Language Writing, 12, 245-265.

Hyland, K. (2002). Authority and invisibility: Authorial identity in academic writing. Journal of Pragmatics, 34, 1091-1112.

Ivanic, R., \& Camps, D. (2001). I am how I sound: Voice as self-representation in L2 writing. Journal of Second Language Writing, 10, 3-33.

Kent, T. (1993). Paralogic Rhetoric: A Theory of Communicative Interaction. Lewisburg, PA:Bucknell University Press.

Knott, D. (2005). Critical reading towards critical writing. Writing at the University of Toronto. [Online] Available: http://www.utoronto.ca/writing/critrdg.html (July 23, 2009)

Liaw, M. L. (2007). Content-based reading and writing for critical thinking skills in an EFL

context. English Teaching and Learning, 31, 45-87.

Liu, D. (2005). Plagiarism in ESOL students: Is cultural conditioning truly the major culprit? ELT Journal, 59, 234-241.

Massi, M. P. (2001). Interactive Writing in the EFL Class: A Repertoire of Tasks. The Internet

TESL Journal, (6). [Online] Available:http://iteslj.org/ (July, 20, 2009)

Matsuda, P. K. (2001). Voice in Japanese written discourse: Implications for second language writing. Journal of Second Language Writing, 10, 35-53.

Nelson, G., \& Carson, J. (2006). Cultural issues in peer response: Revisiting "culture.” In K. Hyland \& F. Hyland, Feedback in second language writing: Contexts and issues (pp. 42-59). New York: Cambridge University Press.

Pithers, R. T., \& Soden, R. (2000). Critical thinking in education: A review. Educational Research, 42, 237-249.

Ramanathan, V., \& Atkinson, D. (1999). Individualism, academic writing, and ESL writers. Journal of Second Language Writing, 8, 45-75.

Sert, N. (2006). EFL student teachers' learning autonomy. Asian EFL Journal, 8(2). [Online] Available: http://www.asian-efl-journal.com/ (July13, 2009)

Stapleton, P. (2001). Assessing critical thinking in the writing of Japanese university students: Insights about assumptions and content familiarity. Written Communication, 18, 506-548.

Stapleton, P. (2002). Critiquing voice as a viable pedagogical tool in L2 writing: Returning the spotlight to ideas. Journal of Second Language Writing, 11, 177-190.

Scollon, R., Tsang, W. K., Li, D., Yung, V., \& Jones, R. (1998). Voice, appropriation, and discourse representation in a student writing task. Linguistics and Education, 9, 227-250.

Swain, M., \& Lapkin, S (2002) Talking it through: two French immersion learners' response to reformulation. International Journal of Educational Research, 37, 285-304.

The New London Group. (1996). A pedagogy of multiliteracies: Designing social futures. Harvard Educational Review, 66, 60-92.

Yarbrough, Stephen R. (1999). After Rhetoric: The Study of Discourse beyond Language and Culture. Carbondale: Southern Illinois University Press. 
To think critically in writing

(e.g. the ability to accept, reject or suspend judgment of other people's ideas)

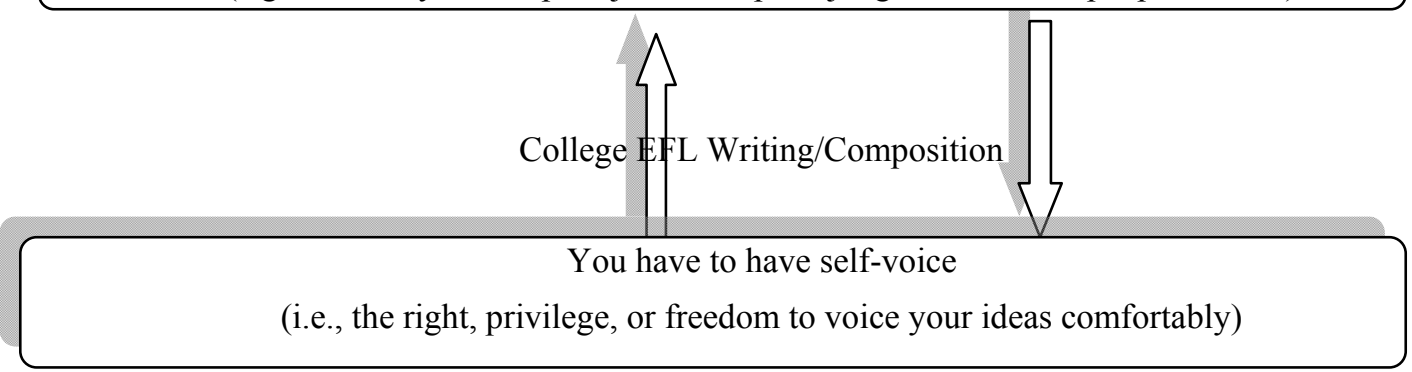

Figure 1. Critical thinking and self-voice as dual competencies in the EFL college writing classroom

\begin{tabular}{|l|l|}
\hline Contrastive-critical framing & Transformed practice \\
\hline 6.Compare and contrast their papers & 10.Revise the draft of their papers \\
7.Indentify problems in the paper & 11.Gain awareness of production \\
8.Negotiate these problems in the paper & 12.Gain idea-transforming skills \\
9.Reach an agreement about the problems & \\
\hline
\end{tabular}

Figure 2. A global picture of the process of contrastive-critical framing and transformed practice. 